Bentham OPEN
CrossMark

REVIEW ARTICLE

\title{
Applying Sustainable Development Principles and Sustainable Operating Practices in Shale Oil and Gas Production
}

\author{
Deborah J. Shields* \\ Colorado State University, Fort Collins, CO 80523, USA
}

Received: July 23, 2015

Revised: September 22, 2015

Accepted: August 12, 2015

\begin{abstract}
Shale oil/gas is one of the most rapidly growing types of unconventional fossil fuel development and the abundance of this resource has postponed peak oil and gas. Physical scarcity of hydrocarbons is now less likely to occur in the near future; however, the likelihood of social scarcity is increasing. Despite the clear economic benefits of production in terms of jobs, tax revenue, and the provision of energy resources and industrial feedstocks, there is hostility toward shale oil/gas extraction in many parts of the world. This is due to concerns about how environmental, social, and economic impacts are managed and mitigated,and how risks and benefits are distributed among industry, governments and civil society. The application of sustainable development principles and sustainable operating practices is recommended as a partial remedy for this situation. Sustainability accounting frameworks based on criteria and indicators of sustainability and best practice codes of conduct represent two possible approaches for tracking how sustainable a firm's practices are. These also provide a foundation for corporate social responsibility and can assist firms in gaining social license to operate. Also needed are estimates of a given operation's net contribution to sustainable development. Possible methods include benchmarking against industry standards, achieving mature business conduct, gaining sustainability certification, demonstrated use of both design for environment and shared value creation methodologies, and integrated sustainability assessment. Conceptual progress has been made in applying sustainability to shale oil/gas; however, significant progress in applying these tools and methods in the field is needed because the sector tends to be judged by the behavior of the least responsible firm. Moreover, if best practices and shared value creation are set aside during the current or a future downturn, public cynicism about the sector will increase, and social license may be lost and even more difficult to regain.
\end{abstract}

Keywords: Economics, Energy, Shale, Sustainability.

\section{INTRODUCTION}

Systems need energy to be ordered and functional. For example, in the absence of continuous inputs of energy in the forms of plowing, planting, weeding, fertilizing, and harvesting, agricultural lands will revert to their prior, natural state, be that forest, shrubland, or steppe. The same is true of economies, which have over many centuries developed into complex ordered systems of machines, buildings, products and services through continuous and increasing inputs of energy.

Initially, most of the energy utilized by societies came from wind, water, animals and humans themselves. But fossil fuel-based energy became widespread during the Industrial revolution, and according to Deirdre McCloskey [1], was in no small part responsible for the 'Great Enrichment' occurring during that period and thereafter. Her views are echoed by other writers $[2-4]$.

Today it is recognized that hydrocarbons are vital to human well-being - integral parts of developed, modern societies. They are essential components of economic systems; and are or could be the driving force for some local, regional, and national economies, providing local employment opportunities and industry expenditures, as well as tax revenues [5]. Measures of economic well-being, such as Gross Domestic Product, increase when access to energy is

\footnotetext{
* Address correspondence to this author at the Colorado State University, Fort Collins, CO 80523, USA; E-mail: Deborah.shields@colostate.edu
} 
increased because it is key to development. This is one reason why the United Nations has created the Sustainable Energy for All program [6]. As UN Secretary -General Ban Ki-moon stated, "Energy is the golden thread that connects economic growth, increased social equity, and an environment that allows the world to thrive"[7]. Moreover, it is estimated that an additional 3 billion people will join the global middle class by 2050 [8]. Middle class life is heavily energy dependent; when people can afford to do so they buy cell phones, TVs, computers, cars, etc all of which require energy.

Much of this needed energy is currently generated by burning hydrocarbons. Despite desire to and efforts toward increasing the use of renewable energies, the percent provided by fossil fuels has remained remarkably steady approximately 85 percent between 2003 and 2013 [9]. Given that alternative energy technologies, such as nuclear and renewables, will be unable to fully meet society's needs in the short to medium terms, there is naturally concern about depletion of hydrocarbon resources. Maggio and Cacciola [10] predicted that conventional oil would peak between 2009 and 2021 and conventional natural gas between 2024 and 2046. A simplified explanation of Hubbert Peak oil and gas is that it represents a point in time when half of the ultimate stock of a resource has been produced [11]. Thereafter production will inevitably decline. Exact peak dates are thought to be less important than the reality of eventual depletion and the consequent need to shift to alternative energy sources.

Moreover, even assuming society could quickly shift to a low carbon energy future, hydrocarbons would still be essential because they are core industrial feedstocks. Natural gas condensate is a raw material, the basic input for the organic chemicals industry (ethylene, propylene, which are the basis for plastics), hydrogen production, fertilizers, and liquid fuels [12, 13]. Businesses locate their manufacturing facilities where they have efficient and low cost access to raw materials, which means that developing shale oil/gas directly leads to economic development opportunities in downstream industries where these resources are utilized [14, 15].

Fortunately, peak oil/gas appears to have been postponed, not least because of technical advancements that enable economic production of unconventional resources. Conventional oil and gas deposits consist of porous reservoirs in geologic formations, capped by an impervious rock 'trap' within which migrating fluids such as oil, natural gas and water accumulate. The distribution of oil or natural gas throughout a geologic formation over a wide area, but not in a discrete reservoir, is called an unconventional deposit [16].

Shale oil/gas is one of the most rapidly growing types of unconventional fossil fuel development. These are heterogeneous deposit types in which oil or natural gas is distributed throughout low-permiability shale formations. Burning natural gas yields fewer greenhouse gas emissions than does burning wood, coal or petroleum. As a result, conventional or shale gas can be substituted for these other fuels, assisting nations in achieving their goals of reducing GHG emissions. Some authors now see abundant shale gas as either a transition fuel to renewable energy sources, or a complementary component of power systems and a hedge against the intermittent nature of renewables [17].

As the International Energy Agency [18] has pointed out, "the boost that [shale gas] would give to gas supply would bring a number of benefits in the form of greater energy diversity and more secure supply in those countries that rely on imports to meet their gas needs, as well as global benefits in the form of reduced energy costs. " This reality is clearly of interest in the United States [5], Europe [19], and China [20] among other countries and regions. The geopolitical ramifications of shale alluded to in the previous quote are playing out in Poland, which is largely dependent on gas and oil imports from Russia [21]. Public reporting on shale gas production and subsequent public debate have been framed mostly in geopolitical terms, with relatively less attention paid to technical issues. Public support for shale gas production is high [22].

Although shale resources are thought to be very large and widely distributed, their recovery is complex and often expensive. Occurrences of this type require special production techniques that often involve horizontal drilling into the gas or oil-bearing formation, followed by hydraulic fracturing of the rock to release the hydrocarbon from the rock. These extraction techniques are deeply controversial [23]. There are serious concerns about the possibilities for environmental degradation, as well as the potential for negative impacts on human health and communities [24 - 31]. The concerns stem in part from public perceptions that the hydrocarbons industry does not:

- manage risk adequately,

- act transparently, or

- create benefits for society.

There is also concern that abundant shale resources will actually postpone a shift to a post-carbon economy and 
result in increased GHG emissions [32]. France, Bulgaria, the Czech Republic and the Netherlands, among others, have banned hydraulic fracturing [33]. Controversies continue in the United States, the United Kingdom, Argentina, and other countries [34 - 36].

Thus, a dynamic tension exists between potential benefits and costs of hydrocarbons, and specifically with respect to expanding shale oil/gas production. Industry has increasingly tried to address the concerns of civil society and governments through the use of best practices, but nonetheless resistance to shale development persists. Hodge [37] addresses what he sees as a seeming paradox: company environmental and social performance is definitely improving, but rather than leading to reduced conflict, opposition is increasing in many locations. He suggests that there needs to be a foundation of sustainability practice and sustainable development (SD) within the sector, combined with efforts to achieve consensus among industry, governments and stakeholders.

This paper reviews the current literature on sustainability, corporate social responsibility, and the social license to operate in the context of shale development. The purpose is not to catalogue specific concerns and practices, but rather to provide an overview of the current understanding of how SD principles and sustainable practices apply to nonrenewable resources in general, and shale specifically. The practices are in large part responses to public and governmental concerns about environmental, social and economic impacts. Approaches for estimating shale oil/gas's contribution to sustainable development are then presented. Conclusions about the state of sustainability practice in shale oil/gas are drawn and steps forward proposed.

\section{SUSTAINABILITY AND SHALE}

\section{Sustaining Physical Availability}

There are many ways to think about shale oil/gas and sustainability. One is the ability of industry and governments to sustain the supply of resources to societies and economies. An inability to do so leads to scarcity. Resources become scarce due to depletion of stocks or disruption of flows. There are two perspectives on stock depletion: the fixed stock and opportunity cost paradigms [38]. The fixed stock paradigm is based on physical measures and statistical estimates of resources. Given that shale oil/gas resources are finite, continued drilling and production will lead first to scarcity and eventually to exhaustion. However, as noted above, recent technological advances have pushed the time of ultimate depletion into the future.

The opportunity cost paradigm takes an economic perspective. Fewer hydrocarbon discoveries would lead to decreased availability, which would in turn result in rising prices. Increasing price would make previously uneconomic shale plays commercially viable thus increasing supply, but at some point rising price would not lead to more discoveries. Proponents of the opportunity cost paradigm argue that the true physical exhaustion of a nonrenewable resource is not possible because before that could happen, the price would rise to such a level that substitutes would be found. From this perspective, the availability of a resource will be determined by what people are willing to give up for it, i.e., its opportunity cost [38]. In reality, energy markets currently face the opposite situation, abundant resources driving prices down.

The third type of scarcity addresses flow through the economic system; it is distinct from the preceding measures of scarcity in that they address the relative abundance of resource stocks. Shields and Šolar [39] define flow disruption in terms of such situations as a temporary cessation of production, political actions such as embargoes, or an unwillingness by civil society to allow resource production to take place. They categorize these as situational, political, and social scarcity respectively. All of these are relevant for shale gas. Situational scarcity is caused by one or more of a broad set of circumstances that act to limit the flow of resources to markets. Potential causes include demand in excess of current production capacity or a lack of infrastructure, such as no pipelines leading to gas flaring rather than productive use of the resource, inadequate LNG port capacity or import capacity when export capacity is needed, or a shortage of LNG ships.

Political scarcity occurs when the flow of a resource is halted or restricted due to choices made and actions taken by governments. The most obvious example of economically motivated political scarcity is an embargo. One producer or a cartel of producers acts to restrict the flow of natural gas to one or more consuming countries with the goal of punishing an opponent, increasing the market price, or collecting transit fees. Concerns in Europe about disruption of gas supply from Russia in recent years has increased interest in developing indigenous energy resources, but this may not be possible given public opposition [33]. The result could be social scarcity, i.e., limited availability of a resource because citizens believe that the environmental and social costs of production are too great to bear. Giurco et al. [40] redefined 
peak resources to account for such situations, arguing that a resource peak is caused by more than reduced discoveries and decreasing availability; the peak is reached not necessarily when half the resource has been extracted, but when increasing social, economic and environmental costs of production contribute to a decline in production rates, i.e., resource availability decreases because the full costs associated with production are seen as increasingly unacceptable.

\section{Frameworks for Sustainable Development}

Placing shale in the broader context of SD requires a perspective that looks beyond physical availability to address both the costs and benefits of production. This is the case because SD necessitates integrating environmental policies and development strategies so as to satisfy current and future human needs, improve peoples' quality of life, and protect the environment, which we depend on for life support services. However, a distinction needs to be made between the contributions that shale oil/gas resources can make to SD and the sustainability practices undertaken to ensure that the contribution of a specific operation is a net positive over its life of the operation. Moran and Kunz [41] write that how the monetary worth/wealth generated by mineral and hydrocarbon supply, demand and use is distributed across people, places and over time is indicative of the resource's contribution to sustainable development. They recommend assessing SD with respect to energy and minerals in terms of equity, with equity in turn assessed based on four criteria: the degree to which future needs will be met, the enhancement of prosperity of the supplying country, the satisfaction of the receiving country, and the acknowledgement and assurance of profitability for business.

This comprehensive, high-level perspective is not found in other frameworks linking hydrocarbons and sustainable development. Most widely found is the triple bottom line (TBL) approach. It acknowledges the interconnected and overlapping nature of social, economic, and environmental realms (sometimes expanded to include governance or other areas). The IPIECA [42], for example, has described the overlapping domains of the TBL with specific application to the oil and gas sector, but this was done not to provide an overarching SD framework or to determine the industry's contribution to sustainable development. Rather, the purpose was to assist current and future oil and gas companies in improving the quality and consistency of voluntary reporting on their environmental, health and safety, social and economic performance. In addition to the areas of economic growth, social progress, and environmental stewardship, they described the socio-economic, socio-environmental and eco-efficiency overlap areas.

Another commonly used framework is based on the maintenance of capital. Here, SD is defined as managing resources in a way that is conducive to long-term wealth creation and the maintenance of natural, social, human, economic/financial, and manufactured/built physical/engineered capitals [43].This perspective extends naturally to shale oil/gas, which is a form of endowed, natural wealth that is an important source of monetary wealth creation and is the raw material for many manufactured and built products. The five capitals approach is widely used, mostly in a descriptive manner, but there is potential to use it as an integrating framework [44].

One area of continued debate within the 5 capitals framework for sustainability is the degree to which different forms of capital can be substituted for each other. Two alternative perspectives are presented in the literature, although in reality they exist at the ends of a continuum. The strong sustainability view is that the opportunities for trade-offs are quite limited, and at the extreme that no form of capital (and especially natural capital) can decrease over time. Under weak sustainability, trade-offs among forms of capital are permitted, with the caveat that overall capital should remain constant or increasing [45]. At its extreme all substitutions among capitals are acceptable, even in cases where irreplaceable cultural heritage sites or environmental assets are comprised or lost. But, assuming that trade-offs are deemed acceptable, there remains significant disagreement about the relative importance that should be assigned to different forms of capital, i.e., how much built physical capital is required to offset the loss of an ecosystem or the depletion of a nonrenewable resource? These are value ${ }^{\mathrm{ii}}$ judgments, which differ across individuals, groups within society, and between nations, making consensus difficult to reach [46].

A related concern is the degree to which societies should assume that technological advancements will continue to expand opportunities for substitution. To date, this has been the case. Societies' access to resources has been greatly

\footnotetext{
${ }^{\mathrm{i}}$ In this context, the term equity refers to fairness. Many economists use the term equity as a synonym for justice, with justice in turn being respect for people's rights. D. Hausman and M. McPherson, Economic Analysis and Moral Philosophy. Cambridge, UK: Cambridge Univefrsity Press, 1996.

${ }^{\text {ii }}$ Value judgements are statements based on subjective views of right/wrong or good/bad that cannot be described as true or false on objective grounds. This leads to the possibility of a pluralistic system of ethics. Hence, one person may believe that a specific state (of for example environmental health) is better than another and so place greater value on its attainment than someone who holds a different ethical view about nature. K. Rothschild, Ethics and Economic Theory. Brookfield, VT: Edward Elgar, 1993.
} 
enhanced, horizontal drilling and fracturing being obvious cases in point, with shale oil/gas being substituted for conventional resources. Should continued breakthroughs be presumed? If so, this would lead to a set of policy prescriptions vis a vis shale resources predicated upon weak sustainability. Conversely, the pace of technical progress might slow, which would imply alternative decisions with a bias toward strong sustainability. Also, as Mulder, Ferrer and van Lente [47] point out, each technological advance will likely come with its own set of contributions, but also paradoxes. This suggests that advances will have unintended, and unanticipated, consequences. If this is the case, the logical conclusion is that shale best practices and policies should be adaptable rather than rigid so as to be responsive to inevitable unexpected circumstances.

Parallel is the question of technology's role in and contribution to sustainability. Advances that lead to more efficient, lower cost production are necessary, particularly in given current low oil and gas prices, but that is no longer deemed sufficient by society.

An activity is deemed efficient if the monetary value of the activity, its benefits, exceeds the monetary value of economic resources allocated to perform the activity, i.e., its costs. This is a rational approach, with the caveat that not all benefits or costs can either be monetized or are considered worthy of inclusion in a benefit - cost calculation by some persons or groups doing assessments. Each exploration and production opportunity comes with its own mix of environmental, social, cultural and institutional context and constraints, and societies expect the extractive industries to be sensitive to and respectful of the place and people where they plan to work. So, in addition to the complexity of the technological system, there is increasing complexity of designed and cultural information systems, and of accelerating integration of human, natural, and built systems [48]. The milieu in which engineers work has become more complex and the expectations placed on them and the systems they design and run have changed.

In 2009, a select international group of petroleum, mining, metallurgical, civil, and chemical engineers convened to discuss resources and sustainability. They agreed upon the essential components of sustainable engineering [49]:

- Economic: The engineered system is affordable.

- Environmental: The external environment is not degraded by the system.

- Functional: The system meets users' needs-including functionality, health and safety- over its life cycle.

- Physical: The system endures the forces associated with its use and accidental, willful, and natural hazards over its intended service life.

- Political: The creation and existence of the system is consistent with public policies.

- Social: The system is and continues to be acceptable to those affected by its existence.

This intersection of the technical aspects of resource exploitation with the human, environmental and governance aspects has received considerably more thought and emphasis than have conceptual overarching frameworks. A variety of sustainability accounting frameworks have been created that typically comprise a list of items that should (or must in the case of certification) be measured and reported upon on a regular basis, or a set of actions or best practices that should be followed, often accompanied by measures to demonstrate that the best practice has in fact been followed [50].

This process is an extension of goals laid out in Agenda 21, the report of the UN Conference on Environment and Development (Rio Earth Summit) in 1992. It recommended countries develop criteria and indicators of sustainability [51]. Criteria describe what it means to be sustainable. They serve as basis for evaluation, comparison or assessment, and achievement is judged against relevant indicators, which are pieces of information that help people understand where they are with respect to their sustainability goals or in the achievement of best practices, how far they are from where they want to be, and whether they are moving toward or away from their goals. Each indicator is a parameter (a property that is measured or observed) that provides information about the state of a phenomenon, environment, or area with a significance extending beyond that directly associated with the parameter measurement [52]. In the years after the Earth Summit numerous sets of criteria and indicators of SD were proposed at various spatial scales (global, regional, national, community) [53]. Sectoral indicators followed, starting with forestry and then extending to other resource and industrial sectors, including to the extractive industries.

One of the most widely used sets of oil and gas sustainability criteria and indicators are those published by the Global Reporting Initiative [54]. GRI has created reporting guidelines, the most recent version being the G4. Their purpose is to provide a standardized and internationally agreed set of disclosures and metrics for sustainability reporting that are widely applicable across sectors. Sector supplements clarify how the basic reporting should be adapted to the particularities of an industry, in this case oil and gas. The first Oil and Gas Sector Supplement (OGSS) was published in 
2012 [55] and was based on the G 3.1 reporting guidelines. It was developed collaboratively with industry and is cross referenced to the previously mentioned IPIECA reporting guidelines. GRI sets out 9 reporting principles, whereas IPIECA has 5 partially overlapping principles and their approach is more general and flexible. A revised version of the GRI OGSS was produced when the G 4 guidelines were published in 2013 [56]. Shale is mentioned, but largely with respect to reporting of resources and reserves and of various GHG or toxic emissions from operations.

In December of 2013 the International Association of Oil and Gas Producers (OGP) and IPIECA published a separate set of good practice guidelines for shale oil and gas that are substantially more detailed than the original reporting guidelines. Issues of concern with respect to shale oil/gas production are identified and best practices recommended for subareas [57]:

1. Worker safety, health and emergency response

a. Safety, health and emergency response

b. Hiring and training

2. Stakeholder engagement and community impacts

a. Open communication and collaboration

b. Noise and visual impacts

c. Traffic and road use

d. Community health

e. Local sourcing and economic development

3. Water sourcing and efficient use
a. Planning process
b. Operations
c. Reuse and recycle

4. Groundwater and surface water protection

a. Detailed site assessment

b. Fracturing fluids and disclosure

5. Cementing and well integrity
a. Overall well intengrity
b. Cementing
c. Well integrity

6. Operational water management
a. Well site design and construction
b. Spill prevention and emergency response
c. Operations
d. Produced water disposal

7. Air emissions
a. Planning process
b. Monitor and reduce

8. Land use
a. Site selection and planning
b. Drilling and operations
c. Reclamation and restoration

9. Biodiversity and ecosystems

a. Open communication and collaboration

b. Opportunity-screening, site selection, project development, operations and decommissioning

c. Prevention and rehabilitation

d. Integrate, adapt and improve

10. Induced seismicity
a. Assessing potential for induced seismicity
b. Monitoring

While these are not specifically intended as the basis for reporting and are not part of the GRI OGSS, indicators for each practice could be developed or actions in each area described, which could be the basis for shale sustainability reporting. The report acknowledges that adaptation to circumstances found in the field should be expected. Given the 
heterogeneous nature of shale plays this is both appropriate and necessary.

In 2012 the International Energy Agency published a report titled "The Golden Rules for a Golden Age of Gas" [58]. They too identified the major environmental and social concerns related to shale gas development and proceeded to list a series of best practices that they developed as a set of "Golden Rules" guiding shale development and decisions by policymakers, regulators, and operators. The focus is on environmental best practice and risk management, and the use of environmental indicators is suggested. The IEA also recommends that the number and type of indicators of best practice must grow as the number of wells drilled increases. This is an acknowledgement of the potential for cumulative impacts. Their idea was that by accepting and implementing these Rules, the level of environmental and social performance would improve and thus public acceptance of shale development would earn the industry a "social license to operate".

Social license refers to the willingness of civil society to accept the presence of an industry in their community. It is not granted by government, but by the impacted communities, a level of trust that must be earned, and is both challenging to maintain and extraordinarily difficult to regain if lost [59]. Loss of social license has significant financial consequences for firms, from public opposition to their operations, questions from lenders, financial institutions that have signed on to the Equator Principles for social and environmental risk management [60], pressure for adverse legislation, and at the extreme violent behavior. Companies report on their operations, i.e., engage in transparency and information sharing, and more broadly in community engagement activities, so as to gain and retain social license to operate. Seeley [61] states that the shale industry must work actively to gain and maintain a social license given widespread public distrust and skepticism that environmental and social issues are being adequately managed.

\section{Assessing Progress Toward Sustainability}

Reporting on indicators is useful, but assessing whether progress is actually being made toward sustainability goals is more complex than simple or minimalistic reporting. There are multiple approaches to assessing effectiveness of sustainable best practices in the shale oil/gas sector. The base level is the completeness of reporting. GRI has created an Application Level protocol under which a firm's reporting under the GRI Framework is graded as C, B, or A based on completeness, with A representing disclosure in every category. Application Level can be self-disclosed, GRI audited or third party audited. When labeled A + the report is stated to have been externally reviewed and assured [54].

Raufflet et al. [62] identified best-in-class companies from the mining and oil and gas sectors with Application Levels of $\mathrm{A}+, \mathrm{A}$ and (in one case) $\mathrm{B}+$. Based on data from and interviews with representatives of these companies, the authors identified 29 corporate social responsibility (CSR) institutional expectations (best practices) in the areas of ethics and governance, environment, community relations, and social, health and safety issues. They recommend that these extractive sector best practices be used as industry standards against which firms should judge their sustainability behavior and their contributions to SD - more best practices indicating greater contribution.

CSR is a form of business behavior that leads firms to voluntarily contribute to a better society and a cleaner environment. Businesses take on commitments beyond common regulatory and conventional requirements, which they would have to respect in any case [63]. The goal of CSR is to raise standards of social development, environmental protection, and respect of fundamental rights by embracing open governance, reconciling the interests of stakeholders, and taking an overall approach to quality. The World Business Council for Sustainable Development describes CSR in the following way [64]:

- a coherent CSR strategy, based on integrity, sound values ${ }^{\mathrm{iii}}$ and a long-term approach, offers clear business benefits to companies and a positive contribution to the well-being of society;

- a CSR strategy provides the opportunity to demonstrate the human face of business;

- such a strategy requires engagement in open dialogue and constructive partnerships with government at various levels, IGOs (inter-governmental organizations), NGOs (nongovernmental organizations) other elements of civil society and, in particular, local communities, and;

- in implementing their CSR strategies, companies should recognize and respect local and cultural differences, whilst maintaining high and consistent global standards and policies; and finally, being responsive to local

\footnotetext{
${ }^{\text {iii }}$ Values here refers to a business's core principles that drive corporate decisions and behavior. Values can set a company apart from the competition by clarifying its identity. They can be strong and meaningful or bland and meaningless. P. Lencioni, Make your values mean something. Harvard Business Review, July, 2002. Available at: https://hbr.org/archive-toc/BR0207?cm_sp=Article-_-Links-_-MagazineIssue, Accessed July 23, 2015
} 
differences means taking specific initiatives."

Moran and Kunz define operating sustainability as how well the activities that create value ${ }^{\text {iv }}$, the measure of an operation's contribution to sustainable development, are undertaken [41]. Operating sustainability is assessed in terms of the maturity of the activities undertaken. They identify four stages of maturity, from least mature (solely profit maximizing) through efficiency focused (eco-efficiency) to integration (taking a more holistic, systems approach) to most mature (adaptable and resilient). The first two of these are straight forward. Firms are initially concerned with short term profit maximization, but eventually become concerned with waste minimization, setting targets for water, chemical and energy usage in stage two. In the third stage the firm takes a more interdisciplinary approach and considers not only local activities, but also the value chain ${ }^{\mathrm{v}}$, the life cycle of the operation and resource, their broader footprint and their modes of information sharing. At the highest level firms develop flexible processes that enable them to be more resilient, i.e., able to withstand externally imposed shocks and return to normal operational/functional mode. It is at this stage that stakeholder preferences become critical.

Equitable Origin (EO) created the EO100 Standard for oil and gas in 2012 [65]. EO is a for-profit social enterprise that promotes best practices in oil and gas operations. They have identified 6 Principles for environmental and social policies:

1. Corporate governance, Accountability and Ethics

2. Human Rights, Social Impact \& and Community Development

3. Fair Labor \& Working Conditions

4. Indigenous People's Rights

5. Climate Change, Biodiversity \& Environment

6. Project Life Cycle Management

EO has recently published a Technical addendum of performance standards for Shale Oil and Gas Operations [66]. There are additional standards added under principles 2 - 6. As with the OGP - IPIECA and IEA best practices, these address the particularities of shale operations and they have points in common with both, for example recommending consideration of cumulative impacts, but they are not identical to either.

EO100 is a verifiable standard and third-party auditors certify projects' performance against the principles and correlated performance standards. The implication is that certified operations make a positive contribution to sustainable development. This approach is analogous to the certification of forest sustainability carried out by groups such as the Forest Stewardship Council (FSC), although they are a not-for-profit organization [67]. The firm must pay EO and the certifier to determine if they meet the standards laid out for certification of their oil or gas operation, which means there needs to be a clear economic benefit to doing so. This has proven to be the case in forestry because purchasers of final goods made of wood want the products they buy to be made from sustainably managed forests, e.g., many manufacturers of doors, tables, paper, garden furniture, prominently display the FSC label on their products because they know this will increase sales. As yet there does not appear to be a clear parallel in hydrocarbon-based consumer products because it would be difficult or impossible to label gasoline at the pump or specific plastic bottles as having been made from sustainable produced hydrocarbons. Alternatively, firms may decide to certify operations to gain social license to operate or to demonstrate CSR. Thus, adoption of the EO100 Standard may be slow; however, it may nonetheless occur if firms believe that having certification will increase their ability to gain or keep social license to operate.

The Lowell Center for Sustainable Production [68] has created a five level indicator framework. In their definition sustainable products are those products being economically viable, healthy for consumers (e.g. not causing injuries), environmentally sound (e.g. considering material efficiency), having production process safe for workers, and being

\footnotetext{
iv The traditional meaning of the phrase to create value is to change business inputs into business outputs in such a way that they have greater monetary value than the original cost of creating those. It is the economic logic for the existence of a company. Moran and Kunz have slightly redefined the phrase for use in a sustainability context, arguing that it is not only how much value is created through business activities, but how that value is distributed across people, places and over time that determines whether a firm is contributing to sustainable development..

${ }^{\mathrm{v}}$ Porter defines the value chain as a series of sequential business activities: inbound logistics, operations, outbound logistics, marketing and sales, and service, all taking place under an overarching set of support activities: firm infrastructure, human resource management, technological development, and procurement. M. Porter, Competitiven Advantage: creating and sustaining superior performance. NY: Free Press, 1985.
} 
beneficial to local communities. This framework was developed as a tool usable by companies to evaluate the effectiveness of their sustainability indicator system. It could contribute to an assessment of SD contribution. Eltayeb and Zailani [69] propose something conceptually similar, though in their case more narrow and applied to supply chains. The process starts with defensive compliance, followed by waste minimization, eco-efficiency, and design for the environment. The focus is industrial ecology and does not consider social issues, reporting, adaptation or resilience. Reaching the highest level means a greater contribution to sustainable development.

Longo [70] proposed that the Lowell approach and Etayeb and Zailani's could be combined with set of social stages to form a more comprehensive picture of company sustainability practices and contribution to SD in the gas sector. In her social hierarchy the first stage is again legal compliance, followed by first corporate philanthropy, then CSR, and ending with shared value creation ${ }^{\mathrm{vi}}$.

Compliance with the law is a clear concept followed by all responsible businesses. The reason that it resides at the bottom of these hierarchies is that it represents a minimum standard. In many cases the law neither requires nor encourages actions that address issues of risk management, community engagement, transparency, or other fundamental aspects of sustainability. Corporations have engaged in philanthropy for many years, though often in ways that do not link to strategic aims [71]. More recently, Porter and Kramer recommended that companies use philanthropy in a way that aligns economic and social goals [72].

Consistent with this view, as oil and gas firms began to engage with civil society in hopes of gaining a social license to operate, they offered grants or gifts in various forms in hopes of gaining acceptance by local governments and civil society. These might be as simple as providing a new fire truck or building a medical clinic, but can be much more substantial. As Morgan [73] points out, "The advantage of a philanthropic approach is that it is simple to provide and usually does not take long to disburse. Moreover, sometimes grants are the only sensible way to support a community. However, donations may reduce incentives for the community to be independent; asking for more social investment has no cost for them. This not only reduces the capacity of the community to deal with their own needs, but also increases costs for companies. And, because social challenges are rarely seen as solved, additional requests normally follow." The results are two-fold: communities want more, but more does not necessarily lead to acceptance or social license.

Philanthropy has since been incorporated as a component of CSR, as discussed above. The most recent extension of corporate social practice is the embrace of shared value creation as an operating principle. As with philanthropy and CSR, the underlying motivation is to earn a social license to operate in the face of growing public distrust of the oil and gas industry, which is accompanied by a failure to understand either how resources are produced or the role of those resources in a complex society.

Shared value in this context means aligning the business interests of extractives companies with community needs and priorities. The goal is to create value in a way that benefits shareholders, but also creates value for society, expanding total value as opposed to redistributing it. Creating shared value in the extractives sectors is not a new concept, but the public perceptions listed above demonstrate that current practices fall short of potential. Hidalgo et al. propose that companies change the existing mindset that sees projects in local communities only as a cost to the business and instead align business interests with community needs and priorities [74].

According to the International Finance Corporation, the shared value process should start with a comprehensive, participatory baseline study of the impacted community's socioeconomic, cultural heritage, and socio-environmental context before project development, after which agreement on joint objectives for the project's community programs is sought. Firms should seek activities that can benefit the project and the community, for example, through imaginative local staff recruitment and training, finding synergies in the provision of infrastructure between development and wider community/country needs, and nurturing local supplier networks for lower cost and better local impact [75]. To the degree that communities are actively engaged, that they experience tangible SD progress that occurs because of the presence of the oil and gas sector, they will be willing to grant a social license to operate. Moreover, if communities welcome companies that practice shared value creation, those firms will gain a competitive advantage. If, on the other hand, business proceeds as usual cloaked in the new language of shared value, communities may well consider this new language to be nothing more than a new version of green wash.

\footnotetext{
${ }^{\text {vi }}$ Shared value creation is in no way related to the idea of convincing people to hold similar moral or ethical beliefs. Rather, it refers to value in terms of social and economic benefits that accrue to the firm and to communities or society in general as a result of business activities. The goal of shared value creation is to undertake business activities in such a way that they generate additional benefits beyond profits and return to shareholders.
} 
In addition to assessing the sector's contribution to SD in terms of CSR behaviors and shared value creation it is also possible to conduct quantitative integrated sustainability assessments (ISA). An ISA is a process through which the costs and benefits of an oil and gas project are assessed in the context of sustainability principles [76]. An ISA

framework should deal with multiple stakeholders with unique objectives, preferences, and levels of risk tolerance, and a decision context with quantitative and qualitative aspects [77]. After problem definition and stakeholder engagement, technical aspects are detailed and economic analyses conducted. The information is brought together using a quantitative tool such as multi-criteria decision modeling and trade-off analysis conducted. The results of the analysis should be communicated to stakeholders with the goal of increasing trust, which would in turn increase the likelihood of gaining social license to operate, but only to the degree that the development approach taken is responsive to the concerns and preferences of civil society [78].

The ISA approach has two weaknesses worth noting. First, not all costs and benefits are easily monetized, and stakeholders may consider putting a monetary value on cultural or spiritual resources offensive. Second, ISA's often use present value analysis ${ }^{\text {vii }}$ to the estimate monetary value of a parameter. This method minimizes the impact of costs or benefits accruing in the far future if a positive interest rate is used.

\section{CONCLUSION}

As this chapter has shown, many authors and organizations are writing about the range of concerns evinced by stakeholders and governments with respect to shale oil/gas extraction. Multiple sets of best practices have been created to guide sustainable operating practices. The sets are overlapping, but not identical because the goals and perspectives of their authors differ. That caveat not withstanding, the core elements are very consistent, suggesting that a consensus on the basic elements of what needs to done in the areas of environmental, social, and economic best practice within the shale sector is emerging. Moreover, there is increasing commitment to corporate social responsibility by companies working in the industry. A variety of methods for estimating the contribution of shale operations to the sustainable development of the regions and communities where they work are available.

Challenges, however, remain. First is the fact that while the major oil and gas firms are adopting these best practices at a high rate, the juniors lag substantially. When a project is initiated by a company that does not use best practices and is then sold to a major, the larger firm may find that social license to operate is limited or even absent and that relationships need to be built or rebuilt with communities. Second, the petroleum sector has always been a boom and bust industry. While communities with a history of extractive industry activity may be willing to accept the cyclic nature of the industry, some shale plays are in areas far removed from historic oil and gas activity. Best practices can help ameliorate the impacts of booms, but the willingness of communities in new areas to tolerate the difficulties associated with busts and still welcome the industry back when markets recover is yet to be determined.

The shale industry is facing a slow-down currently, and prices for oil and gas have dropped precipitously in the past two years. Producers are cutting costs, which has the potential to lead to a third challenge. Sustainable operating practices are not costless; firms will have to decide what they can continue to afford to spend on operations and on social programs. If actions presented as shared value creation or for environmental protection are halted during this or a future downturn, there is a real possibility that stakeholders will suspect that the promises made by industry were not really sincere. In the extractive industries, the sector tends to be judged by the behavior of the least responsible firm. This may be unfair, but it is a reality exacerbated by the industry's lack of willingness to condemn firms that pollute, focus purely on short term profits, or disrupt communities. If best practices and shared value creation are set aside during the current or a future downturn, public cynicism about the sector will increase, and social license may be lost and even more difficult to regain.

\section{CONFLICT OF INTEREST}

The author confirms that this article content has no conflict of interest.

\section{ACKNOWLEDGEMENTS}

Declared none.

\footnotetext{
${ }^{\text {vii }}$ The current worth of a future sum of money or stream of cash flows given a specified rate of return. Future cash flows are discounted at the discount rate, and the higher the discount rate, the lower the present value of the future cash flows. Available at: http://www.investopedia.com/ terms/p/presentvalue.asp, Accessed July 23, 2015.
} 


\section{REFERENCES}

[1] D. McCloskey, Bourgeois Dignity: Why Economics Can't Explain the Modern World., University of Chicago Press: Chicago, 2010. [http://dx.doi.org/10.7208/chicago/9780226556666.001.0001]

[2] A. Maddison, Contours of the World Economy, 1-2030 AD, Oxford University Press: Oxford, 2007.

[3] B. Etemad, and J. Luciani, World Energy Production 1800-1985, Droz: Geneva, 1991.

[4] D. Stern, and A. Kander, "The role of energy in the industrial revolution and economic growth", Energy J. (Camb. Mass.), vol. 33, pp. 125-152, 2012. [http://dx.doi.org/10.5547/01956574.33.3.5]

[5] T. Kinnamon, "The economic impact of shale gas extraction: a review of existing studies", Ecol. Econ., vol. 70, pp. 1243-1249, 2011. [http://dx.doi.org/10.1016/j.ecolecon.2011.02.005]

[6] United Nations, Sustainable Energy for All Initiative, 2012. [April 3, 2015]. Available at: www.un.org/wcm/content/site/ sustainableenergyforall/home/Initiative

[7] Sustainable Energy for all, Available at: www.se4all.org/our-vision/ April 3, 2015

[8] World Business Council on Sustainable Development Vision 2050, 2010. [Sept 16, 2011]. Available at: www.wbcsd.org/WEB/PROJECTS /BZROLE/VISION2050-FULLREPORT_FINAL.PDF/

[9] R. Ridley, "Fossil Fuels will Save the World (Really)", Wall Street, 2015, p. C1.

[10] G. Maggio, and G. Cacciola, "When will oil, natural gas and coal peak?", Fuel, vol. 98, pp. 111-123, 2012. [http://dx.doi.org/10.1016/j.fuel.2012.03.021]

[11] M.K. Hubbert, Nuclear Energy and the Fossil Fuel.Drilling and Production Practice., American Petroleum Institute: Washington, D.C., 1956.

[12] R. Cernansky, "Natural Gas Boom Brings Major Growth for U.S. Chemical Plants. New Haven, CT: Yale Environment 360", 2015. [July 22, 2015]. Available at: e360.yale.edu/feature/natural_gas_boom_brings_major_growth_for_us_chemical_plants/2842/

[13] "U.S. Dept of Energy, Natural Gas Used as Feedstock for Hydrogen Production", 2015. [July 22, 2015]. Available at: www.eia.gov /dnav/pet/pet_pnp_feedng_k_a.htm

[14] "Pennsylvania State University Industrial Use of Natural Gas: Opportunities for the Shale Gas", 2015. [July 22, 2015]. Available at: www.research.psu.edu/events/ expired-events/naturalgas/documents/industrial-uses-position-paper.pdf

[15] A. Krupnick, Z. Wang, and Y. Wang, Industrial Use of Natural Gas: Opportunities for the Shale Gas, Washington, D.C., 2013. RFF

[16] G. Whitney, C. Behrens, and C. Glover, U.S. Fossil Fuel Resources: Terminology, Reporting and Summary. Report 7-5700, R40872., Congressional Research Service: Washington, D.C., 2010.

[17] Leveraging Natural Gas to Reduce Greenhouse Gas Emissions. Arlington, VA: C2ES,. 2013. [April 27, 2015]. Available at: http://www.C2ES.org/publications/ loveraging-natural-gas

[18] Golden Rules for the Golden Age of Gas., International Energy Agency: Paris, 2012.

[19] B. Kavalov, H. Petric, and E. Tzimas, "Evolution of the indigenous European oil and gas sources - recent trends and issues for consideration", Energy Policy, vol. 39, pp. 487-492, 2011. [http://dx.doi.org/10.1016/j.enpol.2010.09.005]

[20] J. Ren, S. Tan, M. Goodsite, B. Sovacool, and L. Dong, Sustainability, shale gas, and energy transition in China, Energy, vol., 2015. (in press)

[21] C. Johnson, and T. Boersma, "Energy (in)security in Poland: the case of shale gas", Energy Policy, vol. 53, pp. 389-399, 2013. [http://dx.doi.org/10.1016/j.enpol.2012.10.068]

[22] R. Jaspal, B. Nerlich, and S. Lemańcyzk, "Fracking in the Polish press: geopolitics and national identity", Energy Policy, vol. 74, pp. 253-261, 2014 [http://dx.doi.org/10.1016/j.enpol.2014.09.007]

[23] H. Boudet, C. Clarke, D. Bugden, E. Maiback, C. Roser-Renouf, and A. Leiserowitz, "Fracking Controversy and communication: using national survey data to understand public perceptions of hydraulic fracturing", Energy Policy, vol. 65, pp. 57-67, 2014. [http://dx.doi.org/10.1016/j.enpol.2013.10.017]

[24] J. Muresan, and M. Ivan, "Controversies regarding costs, uncertainties and benefits specific to shale gas development", Sustainability, vol. 7 , pp. 2473-2489, 2014. [http://dx.doi.org/10.3390/su7032473]

[25] S. Jenner, and A. Lamadrid, S. Jenner, and A. Lamadrid, "Shale gas $v s$. coal: policy implications from environmental impact comparisons of shale gas, conventional gas, and coal on air, water and land in the United States", Energy Policy, vol. 53, pp. 442-453, 2013. [http://dx.doi.org/10.1016/j.enpol.2012.11.010]

[26] M. Broomfield, Support to the Identification of Potential Risks for the Environment and Human Health Arising from Hydrocarbons Operations Involving Hydraulic Fracturing in Europe., DG Environment 07.0307/ENV.C1/2011/604781/ENV.F1: Paris, 2012.

[27] B. Rahm, and S. Riha, "Toward strategic management of shale gas developments: regional, collective impacts on water resources", Environ. 
Sci. Policy, vol. 17, pp. 12-23, 2012.

[http://dx.doi.org/10.1016/j.envsci.2011.12.004]

[28] J. Hughes, "A reality check on the shale revolution", Nature, vol. 494, pp. 307-308, 2013. [http://dx.doi.org/10.1038/494307a]

[29] J. Wang, D. Ryanand, and E. Anthony, "Reducing the greenhouse gas footprint of shale gas", Energy Policy, vol. 39, pp. 8196-8199, 2011. [http://dx.doi.org/10.1016/j.enpol.2011.10.013]

[30] L. McKenzie, R. Witter, L. Newman, and J. Adgate, "Human health risk assessment of air emissions from development of unconventional natural gas resources", Sci. Total Environ., vol. 424, pp. 79-87, 2012. [http://dx.doi.org/10.1016/j.scitotenv.2012.02.018]

[31] R. Alvarez, S. Pacala, J. Winebrake, W. Chameidees, and W. Hamburg, "Greater focus needed on methane leakage from natural gas infrastructure", Proc. Natl. Acad. Sci. USA, vol. 109, pp. 6435-6440, 2012. [http://dx.doi.org/10.1073/pnas.1202407109]

[32] E. Stephenson, A. Doukas, and K. Shaw, "Greenwashing gas: might a 'transition fuel' label legitimize carbon-intensive natural gas development?", Energy Policy, vol. 46, pp. 452-459, 2012. [http://dx.doi.org/10.1016/j.enpol.2012.04.010]

[33] M. Bazilian, A. Pedersen, and E. Baranes, "Prospects for European shale gas", Int. J. Shale Gas Oil, vol. 0, pp. 5-22, 2013.

[34] P. Joskow, "The Shale gas revolution: introduction", Econom. Energy Environ. Policy, vol. 4, pp. 1-4, 2015. [http://dx.doi.org/10.5547/2160-5890.4.1.pjos]

[35] S. Whitehead, Shale Gas - Getting the Message Right in the United Kingdom, 2014.

[36] D. Mares, "Argentina’s shale developments - on track?", Int. J. Shale Gas Oil, vol. 2, pp. 29-32, 2014.

[37] R.A. Hodge, "Mining Company performance and community conflict: moving beyond a seeming paradox", J. Clean. Prod., vol. 84, pp. 27-33, 2014.

[http://dx.doi.org/10.1016/j.jclepro.2014.09.007]

[38] J. Tilton, "On borrowed time? Assessing the threat of mineral depletion", J. Econ. Hist., vol. 63, pp. 612-613, 2003.

[39] D. Shields, and S. Šolar, Responses to Alternative Forms of Mineral Scarcity: Conflict and Cooperation., Rethinking Environmental Conflict: Scarcity, Degradation and the Development of International Cooperation., MIT Press: Cambridge, MA, 2011, pp. $239-285$. [http://dx.doi.org/10.7551/mitpress/9780262014977.003.0010]

[40] D. Giurco, T. Prior, G. Mudd, L. Mason, and J. Behrisch, "Peak Minerals in Australia: A Review of Changing Impacts and Benefits". Sydney: The Institute for Sustainable Futures (University of Technology, Sydney) and Department of Civil Engineering (Monash University), 2010.

[41] C. Moran, and N. Kunz, "Sustainability as it pertains to minerals and energy supply and demand: a new interpretative perspective for assessing progress", J. Clean. Prod., vol. 84, pp. 16-26, 2014 [http://dx.doi.org/10.1016/j.jclepro.2014.09.008]

[42] Oil and Gas Industry Guidance on Voluntary Sustainability Reporting., IPIECA: London, 2005.

[43] S. Shields, and S. Šolar, Sustainable development and minerals: measuring mining's contribution to society, In: Sustainable Minerals Operations in the Developing World, Geological Society Special Publications, 250, Geological Society London: London, 2005 , pp. 195-212.

[44] C. Moran, D. Franks, and L. Sonter, "Using the multiple capitals framework to connect indicators of regional cumulative impacts of mining and pastoralism in the Murray Darling Basin", Resour. Policy, vol. 38, pp. 733-744, 2013. [http://dx.doi.org/10.1016/j.resourpol.2013.01.002]

[45] R. Ayres, J. van den Bergh, and J. Gowdy, "Strong versus weak sustainability", Environ. Ethics, vol. 23, pp. 155-168, 2001. [http://dx.doi.org/10.5840/enviroethics200123225]

[46] D. Shields, S. Šolar, and W. Martin, "The role of values and objectives in communicating indicators of sustainability", Ecol. Indic., vol. 2, pp. 149-160, 2000. [http://dx.doi.org/10.1016/S1470-160X(02)00042-0]

[47] K. Mulder, D. Ferrer, and H. van Lente, What is Sustainable Technology., Greenleaf Publishing: Sheffield, UK, 2011. [http://dx.doi.org/10.9774/GLEAF.978-1-907643-41-5_2]

[48] B. Allenby, The Theory and Practice of Sustainable Engineering., Prentice Hall: New York, 2012

[49] Engineering Solutions for Sustainability: Materials and Resources., Workshop Report and Recommendations. Hoboken: NJ: Wile, 2012.

[50] C. Moran, and S. Lodhia, "N, Kunz, and D. Huisingh, "Sustainability in mining, minerals and energy: new processes, pathways and human interactions for a cautiously optimistic future", J. Clean. Prod., vol. 84, pp. 1-15, 2014. [http://dx.doi.org/10.1016/j.jclepro.2014.09.016]

[51] "United Nations Commission on Sustainable Development (UNCSD)", In: Agenda 21 - Report of the United Nations Conference on Environment and Development. United Nations, New York, 1992.

[52] E. Lammerts van Bueren, and E. Blo, Hierarchical Framework for the Formulation of Sustainable Forest Management Standards, Tropenbos Foundation: Leiden, NE, 1997. 
[53] R. Villas Bôas, D. Shields, S. Šolar, P. Anciaux, and G. Önal, A Review on Indicators of Sustainability for the Minerals Extraction Industries, Rio de Janeiro, BR: CETEM/MCT/CNPq/CYTED/IMPC, 2005.

[54] "Global Reporting Initiative, G4 Global Reporting Guidelines.", Amsterdam: GRI, 2013. [November 10, 2014]. Available at: www.globalreporting.org/resourcelibrary/GRIG4-Part1- Reporting-Principles-and-Standard-Disclosures.pdf

[55] "Global Reporting Initiative, Sustainability Reporting \& Oil and Gas Sector Supplement", Amsterdam: GRI, 2012. [October 3, 2012]. Available at: www.globalreporting.org/ resourcelibrary/G3-1-English-Oil-and-Gas-Sector-Supplement.pdf

[56] "Global Reporting Initiative, G3.1 OGSS Content Index cross-referenced to IPIECA Guidance", Amsterdam: GRI, 2012. [October 3, 2012]. Available at: www.globalreporting.org/ resourcelibrary/GRI-G4-Oil-and-Gas-Sector-Disclosures.pdf

[57] "OGP \& IPIECA", In: Good Practice Guidelines for the Development of Shale Oil and Gas. OGP Report No. 489, The International Association of Oil \& Gas Producers and IPIECA: London, 2013.

[58] Golden Rules for the Golden Age of Gas., International Energy Agency: Paris, 2012.

[59] D. Shields, S. Šlar, and W. Langer, "Sustainable development and industrial minerals", In: J. Kogel,, J. Kogel,, N. Trivedi,, J. Barker, and S. Krukowskieds, Eds., Industrial Minerals and Rocks: Commodities, Markets, and Users. - $7^{\text {th }}$ Edition, Littleton, CO: Society for Mining, Metallurgy, and Exploration, 2006, pp. 133-141.

[60] "Equator Principles Association", London: EPA, 2013. [February 11, 2014]. Available at: www.equator-principles.com/index.php/ep3/ep3

[61] R. Seeley, "Shale’s social License", Oil Gas J., vol. 3, p. 12, 2015.

[62] E. Raufflet, L. Barin Cruz, and L. Bres, "As assessment of corporate social responsibility practices in the mining and oil and gas industries", J. Clean. Prod., vol. 84, pp. 256-270, 2014. [http://dx.doi.org/10.1016/j.jclepro.2014.01.077]

[63] Directorate-General for Employment and Social Affairs, Promoting a European Framework for Corporate Social Responsibility., European Commission: Brussels, 2001.

[64] R. Homes, and P. Watts, Corporate Social Responsibility: Making Good Business Sense., World Business Council for Sustainable Development: Geneva, 2000.

[65] E. Origin, "EO100 Standard.", Available at: www.equitableorigin.com/eo100-standard Equitable Origin: New York, 2012. [April 17, 2015]

[66] E. Origin, "EO100 Standard - Technical Addendum Shale Oil and Gas Operations", Equitable Origin: New York. NY, 2015. [April 17, 2015]

[67] Forest Stewardship Council, "Forests for all Forever Mission and Vision". Available at: ic.fsc.org/index.htm 2015. [May 1, 2015]

[68] A New Way of Thinking., University of Massachusetts: Lowell, 2009.

[69] T. Eltayeb, and S. Zailani, "Going green through green supply chain initiatives towards environmental sustainability", Operat. Supply Chain Manage., vol. 2, pp. 93-110, 2009.

[70] M. Longo, "Gaspipeline Projects: Sustainable Supply Chain Issues", M.S. thesis, Politecnico di Torino, 2014.Torino, IT

[71] J. Gatlin, "An examination of strategic philanthropy and corporate social responsibility communication patterns among the world's twentyone largest oil companies", Int. J. Bus. Soc. Res., vol. 2, pp. 113-121, 2012.

[72] M. Porter, and M. Kramer, "The competitive advantage of corporate philanthropy", Harvard Bus. Rev., vol. 80, no. 12, pp. 56-59, 2002.

[73] R. Morgan, Involving Extractive Industries in Local Communities: The Case of Anglo American. vol. 2, 2013. Available at: ecdpm.org/greatinsights/growth-to-transformation-role-extractive-sector/involving-extractive-industries-local-communities-anglo-american

[74] C. Hidalgo, K. Peterson, and D. Smith, Extracting with a Purpose, Washington, D.C., 2014. Available at: ecdpm.org/great-insights/growth-totransformation-role-extractive-sector/involving-extractive-industries-local-communities-anglo-american

[75] The Art and Science of Benefit Sharing in the Natural Resource Sector., IFC: Washington, D.C., 2015.

[76] J. Jager, and L. Bohunovsky, "Methods and Tools for Integrated Sustainability Assessment", In: Project Summary, Sustainable Europe Research Institute: Vienna, 2008. [September 13, 2009]

[77] G. Finnveden, M. Nilsson, J. Johansson, A. Persson, A. Moberg, and T. Carlsson, "Strategic environmental assessment metholologies applications within the energy sector", Environ. Impact Assess. Rev., vol. 23, pp. 91-123, 2003.

[http://dx.doi.org/10.1016/S0195-9255(02)00089-6]

[78] D. Shields, F. Verga, and G.A. Blengini, "Sustainability versus Sustainable Development: the case of shale gas", In: Proceedings of the SPE EUROPEC and European Association of Geoscientists and Engineers Joint Conference, 2013, pp. 1-7. [http://dx.doi.org/10.2118/164822-MS]

(C) Deborah J. Shields; Licensee Bentham Open.

This is an open access article licensed under the terms of the Creative Commons Attribution-Non-Commercial 4.0 International Public License (CC BY-NC 4.0) (https://creativecommons.org/licenses/by-nc/4.0/legalcode), which permits unrestricted, non-commercial use, distribution and reproduction in any medium, provided the work is properly cited. 